\title{
Paton's Sublime: Race, Landscape and the transcendence of the
}

\section{Liberal Imagination}

Hermann Wittenberg, University of the Western Cape

In the analysis of South African writing, the concept of the sublimei has thus far played a limited role, reflecting a critical consensus that discourses of the sublime are more properly at home in the European eighteenth century and the romantic movement. If the sublime appears at all in colonial writing, the argument goes, it takes the form of belated, derivative and degraded variants of metropolitan aesthetic models. Thus, according to J.M. Coetzee, the sublime emerges in a "late, tentative, and stunted way in South Africa" (1988: 61). In White Writing, his classic study of the politics and poetics of the South African landscape, Coetzee investigates the complex question "as to why the sublime did not flourish in nineteenth-century South Africa" (1988: 55) and how the picturesque rather than the sublime became a more dominant modein colonial "white writing."

A closer look at some major texts in South African literature, informed by newer, radical theoretical interpretations of the sublime, however reveals a different story. A re-reading of Alan Paton's Cry, the Beloved Country (1948), in what I think is an unexplored light, suggests that non-metropolitan discourses of the sublime, far from being an outmoded rhetoric, could manage and contain the contradictions inherent in the aesthetic appreciation and appropriation of contested colonial landscapes. Indeed, as this paper will show, the sublime, already in the classical philosophical foundations laid by Edmund Burke and Immanuel Kant, is founded on problematic assumptions of racial difference. Rereading colonial discourses of the sublime in the light of the racial underpinnings that inform Burke's and Kant's aesthetic theories and philosophies, can allow us to develop insights into the dynamics of the simultaneous disavowal and foregrounding of race present in much of South Africa's colonial and postcolonial writing.

The current lack of critical interest in the manifestations of the colonial sublime is not surprising, given the unpopularity, generally, of aesthetic approaches to literature in the aftermath of the poststructuralist turn in criticism. In the last decade, the field of cultural theory has however seen a resurgence of critical interest in aesthetics. Terry Eagleton's major revisionist study, The Ideology of the Aesthetic (1990), is only one of numerous radical interventions in a field of study which Berthold Brecht thought was supremely reactionary (Regan1992: 3). Brecht's question "Shouldn't we abolish aesthetics?", deriving from his modernist and Marxist distrust of ideological realms above or beyond social realities, is an index of the discredit into which formal aesthetics had sunk. 
In recent criticism, there has been a shift from analysing the sublimeas type of rhetoric or model of text (Weiskel) to a model of theEnlightenment subject (DeBolla) or a model of ideology (Eagleton). A cursory look at recent critical and theoretical writing indeed shows that aesthetics, and notably, the sublime, has made a substantial come-back in a number of fields. Particularly in postmodernist and feminist theory, the sublime occupies an increasingly important role in contemporary cultural debate.J ean-Francois Lyotard's theoretical work, for instance, is a sustained engagement with Kant's Critique of Judgement, leading him to declare that the "sublime is perhaps the only mode of artistic sensibility to characterise the modern" (1993:247). In Critical Aesthetics and Postmodernism (1993), Paul Crowther pursues a similar, if more reductionist, analysis aimed at demonstrating that the sublime, despite intellectually "out of fashion" in the present, nevertheless is a precursor to postmodern cultural modes. Similarly, in Postmodern Sublime (1996), J oseph Tabbi decries the fact that mainstream literary theories afford "little room for the un-ironic, expansive gestures that are traditionally associated with the sublime" (1996: ix) despite the fact that the sublime persists as "a powerful emotive forcein postmodern writing, especially in American works that regard reality as something newly mediated, predominantly, by scienceand technology" (1996: ix).

Further interest in the sublime has been advanced by a number of feminist studies which have critiqued the sublime as a gendered model of the subject that occludes women and serves to establish a masculine epistemology. All classical theories of the sublime, including Kant's and Burke's, indeed rely on the fundamental opposition between the beautiful and the sublime, where these opposites correspond to femaleand male sensibilities. As Kant puts it, "thefair sex has just as much understanding, but it is a beautiful understanding, whereas ours should be a deep understanding, an expression that signifies identity with the sublime" (1991: 78). In these revisionist feminist studies, the sublime is not read as a purely aesthetic category nor merely as a rhetorical style, but is seen to function, more generally, as an ideological mode of domination in which a male subject asserts his rational supremacy over an excessive and unrepresentable experience, leading to a triumphantly enhanced sense of identity. As Barbara Freeman, in The Feminine Sublime: Gender and Excess in Women's Fiction puts it, the sublime involves a sexually coded dominance of "male spectatorship" over "objects of rapture" (1995: 3). Similarly forJ acqueline Labbe, in her book Romantic Visualities: Landscape, Gender and Romanticism, the sublime involves the masculine "power of the eye and a proprietary relationship to the landscape" (1998: 37). The above cited studies concern themselves with the sublime as a mode of representing landscapes that reveals a gendered structure of power.

\section{"The ill effects of black" on the imagination}

While theories of the sublime have been used to re-examine phenomena as divergent as sado-masochism, tourism and hypermedia computer technology, surprisingly little

\section{https://repository.uwc.ac.za/}


attention has been given to the sublime in postcolonial criticism and theory.

Gayatri Spivak's close attention to Kant's theories of the sublime in the introductory chapter of her Critique of Postcolonial Reason (1999) is a rare exception. Her analysis of the sublime is a launching pad for a broader deconstruction of the authoritative narratives of Western philosophy which are posited as "universal" but are also at the same time "unmistakably European" (1999:8) as they occlude non-western people. Receptiveness for and delight in the sublime becomes, in Spivak's reading of Kant, the touchstone for this "universal", rational, educated European subject, whereas for the uneducated and uncultured man (Kant's "rohen Menschen") overwhelming and immense natural phenomena are merely terrible. Capacity for the sublime is thus a civilisational marker that distinguishes enlightened subjects from aesthetically less developed peoples. In Kant's philosophical project, Spivak concludes, the "subject as such is geopolitically differentiated" (1999: 26-7) and the sublime is thus imbricated in the "axiomatics of imperialism" (1999: 19).

Spivak does however not use these critical insights to move beyond Kant, to develop a deconstructive reading of Kant's "Analytic of the Sublime" as a theory for analysing how manifestations of the sublime have shaped discourses in the colonial and postcolonial arena. She appears to be more interested in the sublime as a highly specialised philosophical argument than as a discursive practice that has left its mark on colonial culture. Her argument substantially hinges on Kant's singlethrowaway remark about the "rohen Menschen" and ignores a wider body of writing on the sublime, such as the troubling racial disavowal in Burke's celebrated Philosophical Enquiry into the Origin of Our Ideas of the Sublime and the Beautiful.

Burke famously defined the sublime as "delightful horror" (1757: 52) and associated it repeatedly with chaos, blackness and abyssal dark immensity ("all is dark, uncertain, confused, terrible, and sublime to the last degree" (1757:42)). When it however comes to the darkness of black bodies (in Burke's example, a black woman seen by a previously blind child), feelings of sublimity are blocked by "the ill effects of black on his imagination" and give rise merely to "great horror" (1757:145). Blackness, when associated with the body of the native, emerges as the weak spot that short-circuits the aesthetic mechanism of the sublime. Burke describes the sublime more fully as follows:

Whatever is fitted in any sort to excite the ideas of pain, and danger, that is to say, whatever is in any sort terrible, or is conversant about terrible objects, or operates in a manner analogous to terror, is a source of the Sublime; that is, it is productive of the strongest emotion which the mind is capable of feeling. (1757: 13)

Burke solves the philosophical problem of how "pain", "danger" and "terrible objects" can produce the exalted delights of sublime rapture, by arguing (anticipatory of SacherMasoch) that pain and pleasureare not binary opposites; that presence of pain does not

\section{https://repository.uwc.ac.za/}


automatically mean absence of pleasure and vice versa, but that both pain and pleasure are positive qualities, independent of oneanother: "Many peopleare of the opinion, that pain arises necessarily from the removal of pleasure; as they think pleasure does from the ceasing or diminution of some pain" (1757: 3). The sublime then arises when the subject is presented with the prospect of pain and danger (conventionally, a towering mountain or a powerful storm), yet in such a manner that there is no actual physical harm but only the thrilling proximity of peril:

The passions which belong to self preservation, turn on pain and danger; they are simply painful when their causes immediately affect us; they are delightful when we have an idea of pain and danger, without actually being in such circumstances.... What excites this delight, I call Sublime" (1757: 32).

Burke's theory neatly presents the sublime as a mode of containing and managing the terror that arises out the subject's experience of alterity. The delight of the sublime is however but a thin veneer that barely manages to contain the horror of difference and excess that always threatens to erupt out of the real; and as Burke's telling example of the black woman shows, the sublimefails in theface of racial differenceand gives way to absolute terror. Burke's sublime, already an unstableand ambivalent category of feeling that seeks to represent and contain the unrepresentable, unravels in the face of blackness.

Spivak's omission of Kant's own earlier, politically much more revealing Observations of the Feeling of the Beautiful and Sublime (1764) is even more surprising than overlooking Burke's Enquiry. As the title already spells out, Kant's treatise is founded on the by then conventional opposition between the beautiful and the sublime. As in Burke's work, this binary opposition serves as the governing logic for an aggressive, sustained differentiation between male and female. Furthermore, the distinction between the sublimeand the beautiful functions as a template of taste that can be used to beyond the aesthetic domain to judge the merits of various national traits and evaluate the respective worth of ethnic groups. Kant deploys the binary opposition between the sublimeand the beautiful as an ethno-racial categorisation to differentiate between self and other. He proceeds by evaluating the national and ethnic entities of the world according to their predisposition for the either the sublime or the beautiful: the effeminate Italians and the French are distinguished by feelings for the beautiful, but the virile Germans, English, Spanish have a keen capacity for the sublime. The notable exception among European nations are the Dutch who apparently have no aesthetic capacity whatsoever, neither for the sublimenor the beautiful. Kant's scathing comment: "Holland can be considered as that land where the finer taste becomes largely unnoticeable" (1991: 97).

Kant's judgement becomes even more aggressive when it moves into the colonial field.

\section{https://repository.uwc.ac.za/}


For Kant, the capacity for higher aesthetic judgement is singularly lacking outside of Europe. The only "savage race" that displays a "sublime mental character" is the North American Indian who supposedly has a strong feeling for honour and "seeks wild adventures hundreds of miles abroad" (1991: 111). Kant reserves his lowest esteem for Africa:

The Negroes of Africa have by nature no feeling that rises abovethetrifling. Mr Hume challenges anyone to cite a single example in which a Negro has shown talents, and asserts that among the hundreds of thousands of blacks who are transported elsewhere from their countries, although many of them have been set free, still not a single one was ever found who presented anything great in art or science or any other praiseworthy quality, even though among the whites some continually risealoft from the lowest rabble, and through superior gifts earn respect in the world. (1991: 110-111)

In Kant's normativejudgement, a quick pronouncement on supposedly innate aesthetic capabilities ("by nature no feeling that rises above the trifling") can be used to evaluate matters of character, intellect and the capacity for learning and self-improvement. Equally significant and telling is Kant's equation of "Negro" with "slave". In relying on and repeating the argument of Hume, Kant's pronouncements are an exemplary instance of the fixity and stability of racial stereotyping that has occupied postcolonial critics such as Frantz Fanon and Homi Bhabha. Kant's sublime is then a preserve (with minor exceptions) of the European master races as they alone have the rational mind that can transform baser feelings of fear and abjection into a triumph of theimagination.

Theabove brief discussion of Kant's and Burke's philosophical writingis not intended to explore their philosophical argument fully, but merely to show that ideas of racial difference underpin the classical theories of the sublime. While it would be absurd to argue that the sublime is reducible to a theory of race, or even that racial difference underlies loco-descriptive Romantic poetry such as for exampleWordsworth's numerous evocations of the sublime, it would seem inappropriateto read colonial manifestations of the sublime without regard to the way both Kant and Burke sought to define sublimity by using theimages of racial others as deficit models. Furthermore, both writers repeatedly invoke distant and exotic locales -- often terrains of European colonial expansion -- as privileged spaces for sublimity. In colonial discourse, I suggest, the sublime is then less a mode of rhetorical grandeur and loftiness (as in the original Longinian analysis), but more a highly specialised technique of the imagination in which a subject attempts to master and contain a form of alterity (frequently coded as blackness) that is initially excessive, overwhelming, threatening and incomprehensible. The discursiveoperations of the sublime allow a paradoxical mastery of the subject over such excessive and threatening experience, leading to a triumphantly enhanced sense of identity. It is this understanding of the sublime that I will now use as a lens for an analysis of Paton's Cry, the Beloved Country.

\section{https://repository.uwc.ac.za/}




\section{"A Story of Beauty and Terror"}

The sublime, as Burke tells us, is "productive of the strongest emotion which the mind is capable of feeling" and in this broad sense, the creative process that gave rise to Cry, the Beloved Country can be described as a sublime. Emotion is a key term in assessing the novel. Its origins, in the dark cathedralii of Trondheim, arose, as Paton puts it, from "the grip of a powerful emotion" (1986: 268) and in the following three months of travel across Europe and the USA he was "in a fever to write" (1986: 271) and the story "continued to possess" him (1986: 272). Elsewhere, Paton refers to the "tumult of my emotions" (1986: 269). Upon rereading his own novel twenty-five years later, this same emotion "mastered" him (1986: 272) and, as Paton believes somewhat hubristically, it must have evoked "the same emotion in hundreds of thousands, perhaps millions of readers" (1986: 272). Paton never detailed the exact nature of this passionate and overpowering emotion, as if it is itself beyond discourse. That the novel was able to evoke powerful feelings in many of its readers is without doubt, and even harsh critics such as Stephen Watson, who condemns it as a sentimental, politically naive "tearjerker" (1982: 39), confirm the novel's emotive force. In J.M. Coetzee's somewhat uncharitablejudgment, Cry, the Beloved Country only works because of "theintensity of the driving passion" since Paton "had no particular gift for narrative" and his novels "are statically constructed, depending for their effect on character and emotion." (2000: 325).

Not only is the novel entirely suffused with an overpowering affect that sublimely overwhelms its author, but thevery nature of this emotion is, as in the classical Burkean sublime, a peculiar amalgam of simultaneous delight and terror. Many critics havenoted this contradictory and ambivalent nature of the novel's emotive force, without however using the term "sublime". As Tony Morphet puts it, the overpowering emotion which pervades the novel is a strangely paradoxical kind of fear which

is a powerful unifying force in the novel, acting almost as a kind of connective tissue within which the shapes and pattern of experience are lodged... It is the structural unifier, the common emotion felt and shared by everyone and present in everything, but it is also the destroyer, the cancer which eats away and breaks down the will to do good. The medium in which the story lives is itself destructive. (1983: 4)

Similarly, Andrew Nash's analysis avoids the term "sublime" but describes Paton's emotional ambiguity in the precisely the ambivalent and contradictory language that is commonly associated with sublimity: "The beloved country' was to become a source of anguish as well as a source of delight, the threat to its enjoyment was anguish to endure" (1983: 18). Both Morphet and Nash recognise the paradoxical and conflictual nature of this emotion, that, I propose, can be best understood by invoking a postcolonial theory of the sublime. As Paton himself puts it in the foreword of the 1987 edition, it "is a story

\section{https://repository.uwc.ac.za/}


of the beauty and terror of human life" (1988: 5-6). The governing tension of the text, already encapsulated in its title, is the overwhelminglove for the beauty of theland and a simultaneous fear that destruction and racial violence are imminent. In its primary form, Paton's sublime involves the simultaneous presence of contradictory and contesting affective forces: an evocation of the rapturous and thrilling delight of the African landscape, and, at the same time, the looming presence of the blackness and racial retribution that threatens to destroy the colonial settler order.

An exemplary instance of how the disturbing facts of racial displacement and difference structure Paton's sublime evocation of the land is found in the well-known opening passage of the novel. It warrants an extensive citation and closer analysis:

There is a lovely road that runs from Ixopo into the hills. These hills are grass-covered and rolling, and they are lovely beyond any singing of it. The road climbs seven miles into them, to Carisbrooke; and from there, if there is no mist, you look down on one of the fairest valleys of Africa. About you there is grass and bracken and you may hear the forlorn crying of the titihoya, one of the birds of theveld. Belowyou is thevalley of the Umzimkulu, on its journey from the Drakensberg to the sea; and beyond and behind the river, great hill after great hill; and beyond and behind them, the mountains of Ingeli and East Griqualand.

The grass is rich and matted, you cannot see the soil. It holds the rain and the mist, and they seep into the ground, feeding the streams in every kloof. It is well-tended, and not too many cattle feed upon it; not too many fires burn it, laying bare the soil. Stand unshod upon it, for the ground is holy, being even as it came from the creator. Keep it, guard it, care for it, for it keeps men, guards men, cares for men. Destroy it and man is destroyed.

Whereyou stand the grass is rich and matted, you cannot see the soil. But the green hills break down. They fall to the valleys below, and falling, change their nature. For they grow red and bare; they cannot hold the rain and the mistand the streams are dry in the kloofs. Too many cattle feed upon the grass, and too many fires have burned it. Stand shod upon it, for it is course and sharp, and the stones cut under the feet. It is not kept, or guarded, or cared for, it no longer keeps men, guards men, cares for men. The titihoya does not cry here any more. (1988: 7)

Paton's narrative presents the Natal midlands as a landscape deeply invested with affect, as a space intensely charged and suffused with feeling to the point that the capacity of language breaks down (signalled by the word "beyond"). In this characteristic sublime moment of the simultaneous expansion and collapse of discourse, the narrator's lyric reverence in the form of an extended loco-descriptive praise song is insufficient to express the fullness of sentiment. In the narrator's passionate homage, the

\section{https://repository.uwc.ac.za/}


overwhelming beauty of the landscape exceeds representation and is "beyond any singing of it".

At a first glance, this sublimemoment represents a classical colonial prospect scene: the authorial narrative performs a survey of the surrounding landscape from a position of elevation. The sweep of the eye first travels across objects of close proximity ("About you there is grass and bracken"), then takes in the far distance ("the mountains of Ingeli and East Griqualand"), but subsequently, in a panoramic, consciousness-expandingmoment typical of sublime discourse, moves beyond the visible ground to imaginatively take in the unseen but known landscape of the entire Natal ("from the Drakensberg to the sea"). Following numerous studies in postcolonial criticism (see for example Mary Louise Pratt, David Bunn, Anne McClintock), prospect passages such as this could readily be interpreted as a scene staging imaginative colonial mastery and control over a pliant, subjugated colonial terrain, particularly when we consider that the as yet unnamed vantage point that provides the platform for this expansive gaze is later identified as "the farm and dwelling-place of J ames Jarvis, Esquire" (1988:112), the English-speaking white farmer protagonist of the novel. Aptly named "High Place", it is one of settler farms that commands the high ground adjoining the "nativereserve" in the valley below and it is from here that the landowners can look out and control theland from "thelong verandas drinking their tea" (1988:113).

But Paton's use of prospect rhetoric is not easily readable as a triumphalist imperial gesture; in fact the text's already muted deployment of the romantic sublime is almost immediately undercut by a change in direction of the gaze. It soon abandons the expansive horizontal axis with its views to the far-off mountains and instead follows the vertical plane downward. In almost cinematic fashion, the initial sweeping pan shot cuts to high-angle shot that then zooms in to a close-up examination of the valley far below. Thenarrative first describes the condition of the grass and soil on the up-lands, and then the gaze descends into the valley below to reveal the degradation and poverty of the "native reserve." What unsettles the moment of sublime delight is then thereality of the valley, requiring the eye to abandon the high and lofty prospect view and examine the landscape below at ground level ("the stones cut under the feet"). The stark sociopolitical realities of rural Natal undermine, literally from below, the grandiose, sweeping views which the settler farmers might enjoy.

An overall assessment of the passage, and indeed the novel as a whole, suggest then that Paton's use of the sublime is rather more complex and contradictory. The awe-inspiring and overwhelming sublime effect of the landscape does not merely arise from the natural beauty of the land, but is always accompanied by, or rather produced by the underlying facts of blackness and racial difference. The structure of Paton's sublime, effectively a lamination of "beauty and terror", heightens the sense loveliness and poignancy of the landscape by imagining its loss in the racial conflict that threatens to

\section{https://repository.uwc.ac.za/}


engulf South Africa. This juxtaposition of "beauty and terror" becomes a structuring motif in the novel, for example when the narrator asks:

Who can enjoy the lovely land, who can enjoy the seventy years, and the sun that pours down on the earth, when there is fear in the heart? Who can walk quietly in the shadow of jacarandas, when their beauty is grown to danger? (1988: 67)

In the striking image of the jacaranda, Paton shifts the focus from brightness and comforting sunshine to darkness and danger. The jacarandas, exotic trees whose purple blooms are conventionally associated with many white urban landscapes on the highveld, are no longer merely beautiful, leafy avenues that provide delight for the eye and cool shade for residents. Paton sees them as avenues of fear and their shadeis less a refuge than a dark place of danger.

This analysis is confirmed in an untitled article, written at Anerley on the Natal South Coast soon after the publication of Cry, the Beloved Country. In it, Paton sketches the troubling racial landscape of South Africa, and ends with a quotation from his own novel:

We white South Africans, are a conscience-troubled people. Not all our colourful fruits and birds, our beauties of mountain and plain, our long hours of sun, our mineral and other wealth, can distract us from graver, deeper, more anxious thoughts. What I wrote in 'Cry, the Beloved Country' is the plain and simple truth: The sun pours down on the earth, on the lovely land that man cannot enjoy. He knows only the fear of his heart.' (n.d.: PC 1/8/1/1/ 16)

This structure of denied joy and fearful beauty arising from "graver, deeper, more anxious thoughts" can also be discerned in one of the signal passages in the novel that can almost be read as an anti-sublime, repudiating the rapturous delight in the "beauties of mountain and plain" of the South African landscape:

Cry, the beloved country, for the unborn child that is theinheritor of our fear. Let him not love the earth too deeply. Let him not laugh too gladly when the water runs through his fingers, nor stand too silent when the setting sun makes red theveld with fire. Let him not be too moved when the birds are singing, nor give too much of his heart to a mountain or a valley. For fear will rob him of all if he gives too much. (1988: 72)

Although the narrative compellingly foregrounds the dangers of giving oneself to the seductive aesthetic pleasures of theland, there is, in the act of disavowal, a simultaneous passionate evocation of this very same landscape. Even here, a lingering sense the romantic love and delight in the land is not completely obliterated by the underlying

\section{https://repository.uwc.ac.za/}


threat of a racial cataclysm. The facts of black rural poverty and dispossession, and the potentiality of racial retribution and violencearealways inherent in Paton'simagination of the landscape. Paton's sublime, to use Tony Morphet's words, "keeps the full force of contradiction alive" (1983:6).

\section{Youthful Ecstasies}

The degree to which a political awareness in Cry, the Beloved Country intrudes on and disrupts a more innocent romantic vision of the land is remarkable if one considers that only five years before, as Paton admits, he had still "clung to the irrational idea that one could maintain white supremacy and yet bejust" (1986: 240). This political stance, as we shall see, is not entirely absent in the novel. Indeed, traces of Paton's politically "irrational idea" conceal themselves in the very sublime moments of the text, perhaps precisely because the sublimeitself exceeds therational. When Paton started to abandon his supremacist political position, partly due to his experiences at Diepkloof reformatory and serving in the Anglican commission that had been tasked "to define what it believed to be the mind of Christ for South Africa" (1986: 238), this had irrevocable and painful consequences for the way he could imagine the South African landscape. Paton's growing awareness and intense emotive response to the racial problems of South Africa are, in effect, the motor driving the shifts in his aesthetic appreciation of the "beloved country". His capacity to write and evoke sublimity shifts from its roots in an initially romantic, youthful and politically innocent rapture and delight in the landscape to a more complex aesthetic response that reflects a growing maturity and a sustained engagement with the politics of the land, in particular the traumatic question of race. The development of Paton's youthful sublime is described in some detail in the autobiography Towards the Mountain:

I cannot describe my early response to the beauty of the hill and stream and tree as anything less than an ecstasy. A tree on the horizon, a line of trees, the green blades of the first grass of string, showing up against the black ashes of the burnt hills, the scarlet of the fire-lilies among the black and the green, the grass birds that whirred up at one's feet, all these things filled me with an emotion beyond describing. ... I was much older before I responded, and no less intensely, to the beauty of the plain and sky and distant line of mountains. (1986:4-5)

In this passage, Paton refers to two distinct aesthetic modes that shaped his earlier responses to the landscape. The first, corresponding to the period of his boyhood rambles in theveld around Pietermaritzburg, revels primarily in the textures and minute details of nature, an impulse that would continue to shape Paton's later amateur interests in ornithology and botany, fields in which he would become highly competent. Traces of this aesthetic modealso repeatedly influence the descriptions of naturein Cry, the Beloved Country. It is also an aesthetic that was shaped, from early childhood, by a sustained and intense exposure to romanticliterature, especially Robert Burns and R.L.

\section{https://repository.uwc.ac.za/}


Stevenson. Later, while studying at Natal University College, he would imbibe thelarger English canon of poetry. Together with a group of "boy-men" (1986: 63) they would read the poetry of "Shakespeare, Milton, Wordsworth, Coleridge, Keats, Shelley, Byron, Tennyson, Browning" (1986: 63) and recite verse while romantically rambling through the Natal midlands on excursionary walks.

The latter sublime of "the beauty of the plain and sky and distant line of mountains" involves a grander, more expansive vision that goes beyond the minutiae of natural details and the self-absorbed recitation of verse. It is more directly a source of the landscape descriptions in Cry, the Beloved Country, such as in the novel's opening paragraphs. We can trace the development of this sublime to thelate 1920's, the period of Paton's teaching in Ixopo, where the recently graduated young man fell in love with Dorrie, a married woman who was later to become his wife. On the excursionary walks they went on together in the surrounding hills, Paton's passion for his first true love must have fused with the ardour he already felt for thelandscape of Natal. "I was in love with the countryside and its bracken and its mists" (1988:101), Paton writes, and was "[w]alking the hills with an energy that is limitless" (1988:102). He writes of "the intensity of response to this magic country. ... The Ixopo countryside laid me under a kind of spell" (1988:85).

But this landscape, as it is initially described in Towards the Mountain, is not yet the truly sublime space that it would become in Cry, the Beloved Country. While undoubtedly inspiring passion and delight, it lacks the elements of imagined fear and traumatic loss to give it its sublime pathos. As Paton concedes, his youthful ardour was completely evacuated of any sense of political awareness around the question of land ownership and a social concern about the people whoseland it once was: his "great love of the country ... was in those days not a love of its peoples, of whom I knew almost nothing" (1986: 56). It is only Paton's later political understanding that would introduce the painful idea that the beauty of the landscape was threatened by the facts of racial injustice. Indeed, the rolling hills of Ixopo could only become recuperated by the imagination as a sublime space after they had, in reality, become a lost landscape. The language of the following passage, fed by this sense of loss and yearning, is instantly recognizable as part of the sublime discourse of Cry, the Beloved Country:

Much of the beauty of the Ixopo countryside has gone, because the grass and the bracken and the rolling hills and farms have in large part given way to the endless plantations of gum and wattle and pine, and the titihoya does not cry thereanymore. (1986: 86)

Thelandscape of Ixopo, as Paul Rich has pointed out, is written out of nostalgia as it was even then "written on the crest of a profound economic and social transformation in rural Natal which had important consequences for the landscape" (1985: 56).

\section{https://repository.uwc.ac.za/}


An unfinished and unpublished story written by the younger, largely unpoliticised Paton offers us another intriguing glimpse into the pre-sublime Ixopo landscape. "Secret for Seven" (written in the early 1930's) deals with the marriage of Mary Massingham, daughter of an old, genteel, landed Natal family who falls in love with and marries Charles Draper, son of a carpenter. The problem set up in the narrative is not so much one of violating class distinctions (landed old money marrying working class), as the matter of Draper's swarthy mother whose racial identity is dubious ("A dark-skinned woman about whose descent kindly tongues did not enquire"). The theme of miscegenation and race is clear in the moment of crisis: Mary gives birth to their first child, who turns out to beblack skinned. Major and Mrs Massingham arriveand Draper, who must break the news to them, resolves to disown the child, giving it to Catholic nuns. The story ends unfinished, as if Paton is unableto resolvetheintractable problem of race.

Of moreinterest to my argument is the setting of the story. It is, prototypically, the same spatially and racially divided colonial landscape of Cry, the Beloved Country, contrasting the high ground occupied by white settlers with thelow-lying reserve of theZulu people:

A world apart; for when the mists came down over the mountain, they cut off whitefrom black with their level line. Up her the swirling mist, \& wattles dripping eerily in it, \& gates looming suddenly out of it; down there clearness\&stars, \& the cries of natives from kraal to kraal, \&lights here \& there from hut and hut. Up here the farms of white people, houses, wireless, mist; down there the lands of blacks, huts, singing, \&stars. ... She[Mrs Massingham] and her daughter would sit on the verandah of 'Emoyeni', looking down on the valley below at a different world. For there lived the natives in their reserves, a land where no mist came \&no bracken grew \& no titihoyas called; where the earth was red, \& the thorn-tree and the aloe flourished, a hot country where colours were more vivid \& sounds more loud.

The similarities to Cry, the Beloved Country are striking but so are the differences. 'Emoyeni' is Zulu for 'High Place', but thelow-lying "reserve" here is not yet recognised by Paton as the degraded land that speaks of dispossession and racial injustice. Compared to the white farms that are isolated from each other in the cold, swirlingmists of the uplands, the reserve is a scenefull of song, warmth and vibrant life. It is a happy, exotically colourful locale as opposed to the hunger-stricken, rural labour-pool of Ndotsheni. It is clear that "Secret for Seven" cannot achieve the sublimejuxtaposition of Cry, the Beloved Country: the urgency of human suffering and tragic awareness of racial oppression is missing from a scene that is more akin to a tourist postcard.

\section{"Unspeakable sorrow and unspeakable joy"}

In Cry, the Beloved Country, Paton is then fully aware of thestark, racialised divisions of

$$
\text { https://repository.uwc.ac.za/ }
$$


colonial space which produce, on the one hand, elevated settler landscapes of transcendent and wholesome beauty, and on the other, environmentally degraded lowlands of African poverty, malnutrition and social dysfunction. The novel diagnoses the causes of rural poverty and environmental degradation as being rooted in the wholesale colonial dispossession of Africans from their land. As the novel puts it in Arthur J arvis's words: "We set aside one-tenth of the land for four-fifths of the people" (1988:127).

The problem however is that despite the novel's trenchant analysis the colonial land question, settler farms such as J arvis's "High Place" are presented as benign, custodial spaces that somehow respectfully combine agri-business with the preservation of the edenic, natural or imaginary pre-colonial wholeness of the land, keeping it "even as it came from the Creator." Such an account cannot but validate the right to continued ownership. So even as Paton's novel eloquently exposes the injustice of colonial land dispossession and indeed foregrounds theintrinsic structural connections between white wealth and black poverty, his sharp critique of the colonial land question results in at best paternal, ameliorative interventions (supply of milk to malnourished children), or gradualist environmental upliftment which can only fail to change the basic inequitable racial structure of land ownership. Although the novel incorporates and even validates a more radical political critique gesturing towards revolutionary systemic change (J ohn Kumalo and the agricultural demonstrator), these voices can ultimately not shake the affective force of Jarvis's love for his land that dominates the novel. Owning and retaining the "High Places" is non-negotiable in Paton's liberal vision of South Africa. Through the figure of J arvis's orphaned grandchild, who is allowed to recuperate from the menace of J ohannesburg's racial violence, the novel can indulge in the fantasy of continued patrilineal inheritance of white colonial property in Africa. It is an escapist agrarian political solution that nostalgically seeks to validate and revitalise a vanishing paternal rural order of just and strong but compassionate gentlemen farmers, and loyal, simple and honest African rural folk.

In his sublime, Paton is thus able to admit and contain the disturbing facts of blackness, but in such a manner that the overall sense of identification with the land and colonial ownership is not displaced. Paton's sublime, as it finds expression in Cry, is then less about the rapturous effect of indescribable natural beauty, but rather represents that tenuous and illusionary moment in the white liberal imagination where an impossible oneness with the beloved land can be imagined. In a transport away from the trauma of social and political realities, South African white guilt and responsibility are temporarily suspended in a purely affective space in which the subject can be momentarily redeemed in the presence of God's creation.

Such sublime moments of settler transcendence were becoming less sustainable in the contested landscape of South Africa and Paton's other expressions of sublimity invoke

\section{https://repository.uwc.ac.za/}


political and social utopian fantasies of a "promised land", rather than the land itself. Indeed, in the most powerful deployment of sublimity in Paton's oeuvre -- the description of the funeral of Edith Rheinallt-J ones -- the sublime has shifted completely away from the landscape and founds itself in a social event that promises a glimpse of a future non-racial society:

Black people, white people, Coloured people, European and African and Asian, J ew and Christian and Hindu and Moslem, rich and poor, all came to honour her memory, their hates and their fears, their prides and their prejudices all for this moment forgotten. ... As for me, I was overwhelmed, I was seeing a vision, which was never to leave me, illuminating the darkness of the days through which we live now. To speak in raw terms, there was some terrible pain in the pit of my stomach. I could not control it. I had again the overpowering feeling of unspeakable sorrow and unspeakablejoy. (1986: 252 -3)

In this passage, the opposites that structure South African politics, here conceived of primarily in terms of race and religion, merge into a sublime Kantian Aufhebung. But it is primarily racial difference and the illusionary moment ("a vision") of its dissolution into an imaged oneness that is the primary emotive force here in Paton'simagination, for hecan conclude that he "was no longer a white person but a member of the human race" (1986:253). Paton's use of the sublime, as we can clearly see in this passage, is founded on a simultaneous recognition of racial difference (he writes not of "people" but defines them as "Black", "white" and "Coloured") and the collapse of these racial categories. The result is an ecstatic and painful loss of identity that is "unspeakable" and resists full representation. Paton's sublime, as we can see, has fully shifted from the evocation of a beloved landscape to the thrilling vision of the promised land of racial harmony. Of course, the multi-racial homage to J ones that gives rise to Paton's sublime feelings reaffirms the centrality of the good white liberal who selflessly "gave her money, her comforts, her gifts, her home, and finally her life" (1986:253) in the service of black upliftment. The liberal, political vision of South Africa is ultimately affirmed rather than challenged.

\section{“Africa dark and savage"}

But this mode of transcendence -- which we might call Paton's utopian sublime-- is but one mode of sublimity. It is also counterbalanced by another form of rapturous transcendence, a sublime that replaces the vision of racial harmony with the terror of racial retribution. As the novel's narrative moves from the degraded, yet orderly rural world of Natal to the modern urban setting of J ohannesburg, we encounter J ohn Kumalo's powerful black African voice:

There are those who remember the first day they heard it as if it were today, who remember their excitement, and the queer sensations of their bodies as though electricity were passing through them. For the voice has magicin it, and it has threateningin it, and

\section{https://repository.uwc.ac.za/}


it is though Africaitself were in it. A lion growls in it, and thunder echoes in it over black mountains. (1988:158)

Kumalo's voice, just as the vast, rolling expanses of the African landscape of the novel's opening paragraphs, has the capacity to achieve sublime effect. His voice is the landscape, "Africa itself". His consummate oratorical skill is, in the words of a white security policeman "like the great stop of an organ. You can see the whole crowd swaying. I felt it myself" (1988:161). But what is Kumalo saying? His speech pleads for economic justice, for higher wages for workers on the rich goldmines: "We ask only for those things that labouring men fight for in every country in the world, the right to sell our labour for what its worth, the right to bring up our families as decent men should" (1988:159). He also suggests that workers should use their only weapon, namely withholding their labour. This is hardly a revolutionary message, in fact ArthurJ arvis's treatise spells out much the same: "It is not permissible to mine any gold, or manufacture any product, or cultivate any land, if such mining and manufacture and cultivation depend on their success of keeping labour poor." (1988:126). But in a revealing illiberal moment, the narrator twice contemptuously describes Kumalo as a man lacking intelligence, a "bull voice" without brains. So what is it aboutJ ohn Kumalo that makes him the target of aggressive, racist disparagement? Why is he depicted as the stereotypical uppity black man whose rhetorical accomplishments are but a thin veneer over a primitive mind? The key is not in what Kumalo actually says, but what he could say should he want to. Inherent in Kumalo's oratorical mastery is the threat of powerful racial incitement and native uprising: his voice could "paint for them pictures of Africa awaking from sleep, of Africa resurgent, of Africa dark and savage" (1988:158).

If J ohn Kumalo's speech-making contain the germs of a violent black uprising, the archetypal stuff of white settler fears, it also holds the promise of a future black liberation, a goal Paton was publically committed to. Indeed, it is this very political objective that the entire thrust of the novel is ostensibly directed at. But Kumalo's brand of ethnically defined, worker-lead liberation is fundamentally at odds with Paton's paternal Liberalism that still sees responsible and enlightened whites (such as Edith RheinalltJ ones) as the central agency for effecting changein South Africa. In the "white man's burden" argument of ArthurJ arvis's treatise, white colonisation destroyed the old African tribal system and "[o] ur civilisation has therefore an inescapable duty to set up another system of order and tradition and convention" (1988:127). White leadership is thus ultimately required to repair the ill effects of colonisation and lead black Africans into an orderly and rational South African modernity. In such a political vision, revolutionaries such as Kumalo must necessarily be represented as a threatening and destabilising force. In the figure of Kumalo, Paton allows us to imagine a form of transcendence that conjures up images a future mass uprising and of black freedom - a revolutionary sublime that simultaneously appals and fascinates.

\section{https://repository.uwc.ac.za/}




\section{Conclusion}

This paper has tried to trace the influence and extent of the sublime in Paton's Cry, the Beloved Country and other writing. Although the term "sublime" is itself not used in the novel, it is a key discursive structure that shapes the text's complex and ambivalent representation of South Africa's politicised landscape. Paton, reread through this critical lens, emerges perhaps more creditably as a writer intensely alive to the complex politics of race than has been allowed by his numerous critical detractors in the late 1970s and 1980s. Paton's imaginings of transcendence do not evade the racial and colonial trauma of South Africa, but rather embody these very tensions and shape them into an ambivalent and contradictory affective force that can, I think, be best understood in terms of the sublime. Put differently, Paton's sublime that so powerfully pervades his "story of beauty and terror" is unthinkable without the spectre of racial violence as its driving force.

Paton, as we have seen, evokes sublimity in different ways in his writing, ranging from a youthful, innocent rapture in the face of the beauties of the land to a more mature and complex compound of overwhelming terror and exultation that accompany either visions of racial harmony or racial cataclysm. But while Paton's sublime is fed by the fear of a looming racial conflict, it also manages to contain that very fear and transcend its terror. Racial difference and its political consequences are the forces that produce Paton's sublime, but paradoxically, these sublime moments in the text manage and contain the very fears that have produced sublimity in the first place in such a way that intensify the affective force of his love for the land into an ecstatic affirmation of belonging. 


\section{Bibliography}

Alexander, Peter.

Bunn, David.

Burke, Edmund .

Coetzee, J.M.

Crowther, Paul.

Eagleton, Terry.

Freeman, Barbara.

Kant, Immanuel.

Labbe, J acqueline.

Lyotard, J ean-Francois. Docherty (ed.) Postmodernism. A Reader. New York: Harvester Wheatsheaf.

1994 . Lessons on the Analytic of the Sublime. Stanford: Stanford University Press.

Mansfield, Nick.

1994. Alan Paton. A Biography. Oxford: Oxford University Press.

1988. "Embodying Africa: Woman and Romancein Colonial Fiction." English in Africa 15/ 1(May): 1-28.

1757. A Philosophical Enquiry into the Origin of Ourideas of the sublime and the Beautiful. London: R \&J Dodsley.

1988. White Writing: On the Culture of Letters in South Africa. J ohannesburg: Radix.

2001. Stranger Shores. Essays, 1986-1999. London: Secker \& Warburg.

1993. Critical Aesthetics and Postmodernism . Oxford: Oxford University Press.

1990. The Ideology of the Aesthetic. Oxford: Blackwell.

1995. The Feminine Sublime. Gender and Excess in Women's Fiction. Berkeley: University of California Press.

1951 (1790) Critique of J udgement. tr. J .H. Bernard, New York: Hafner.

1991(1764). Observations of theFeeling of the Beautiful and Sublime. Trans. J ohn Goldthwait. Berkeley: University of California Press.

1998. Romantic Visualities. Landscape, Gender and Romanticism. London: Macmillan Press.

993. "The Sublime and the Avantgarde". In Thomas 1997. Masochism. The Art of Power. Westport: Praeger.

\section{https://repository.uwc.ac.za/}


McClintock, Anne.

Morphet, Tony.

Nash, Andrew.

Paton, Alan.

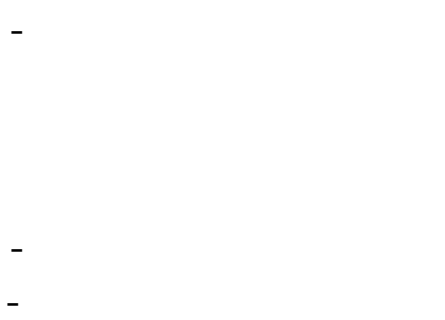

Pratt, Marie Louise.

Regan, Stephen.
1995. Imperial Leather. Race, Gender and Sexuality in the Colonial Context. New York: Routledge.

1983. "The Honour of Meditation”. In English in Africa 10/ 2 (October): 1-10.

1983. "The way to the Beloved Country: History and Individual in Alan Paton's Towards the Mountain." English in Africa 10/ 2 (October): 11-27.

1988 (1948). Cry, the Beloved Country. Harmondsworth: Penguin.

1949. "South Africa's Racial Problems of an intensity and complexity unknown to any other country". Alan Paton Centre: PC 1/8/ 88/ 12.

1980. Towards the Mountain. Harmondsworth: Penguin. n.d. "Secret for Seven". Alan Paton Centre: PC 1/ 3/4/ 6.

1992. Imperial Eyes. London: Routledge.

1992. The Politics of Pleasure. Aesthetics and Cultural Theory. Buckingham: Open University Press.

Rich, Paul.

1985. "Liberal Realism in South African Fiction, 1948 1966". English in Africa 12 / 1 (May): 47 - 81.

Spivak, Gayatri Chakravorty. 1999. A Critique of Postcolonial Reason. Toward a History of the Vanishing Present. Cambridge (Mass.): Harvard University Press.

Tabbi, J oseph.

1995. Postmodern Sublime. Technology and American Writing from Mailer to Cyberpunk. Ithaca: Cornell University Press.

Watson, Stephen. $\quad$ 1982. "Cry, the Beloved Country and the Failure of Liberal Vision" In English in Africa 9/1(May): 29 - 44.

Weiskel, Thomas. $\quad$ 1976. The Romantic Sublime: Studies in the Structure and Psychology of Transcendance. Baltimore: J ohn Hopkins.

\section{https://repository.uwc.ac.za/}




\section{Notes}

i. At a very basic level, two rather simplistic 'definitions' of the sublime may provide a provisional conceptual map. Firstly, the sublime is that which moves one. The sublime is an affective force with power to transform the subject, usually in a manner that is elevating and uplifting, but also potentially terrifying. Secondly, such sublime experience cannot be represented, or at least not fully represented. Any discourse of the sublime also embodies, paradoxically, its own representational failure as the immensity of the sublime object or experience exceeds the capacity of language to represent it.

ii. Cathedrals were a long established commonplace for evocations of the sublime. See for example the following passage by Coleridge:

On entering a cathedral, I am filled with devotion and with awe; I am lost to the actualities that surround me, and my whole being expands into the infinite; earth and air, nature and art, all swell up into eternity, and the only sensible expression left is, 'that I am nothing' (Coleridge quoted in De Bolla, 1989: 44)

ii. “Secret for Seven”, unpaginated and undated manuscript. Alan Paton Centre: PC 1/3/4/6. 